\title{
Kualitas Dendeng Babi Yang Menggunakan Gliserol+NaCl Selama Penyimpanan Pada Suhu Kamar
}

\author{
Merri D. Rotinsulua*, Tilje A. Ransaleleha, F. S. Ratulangia, E. S. Tangkerea \\ aFakultas Peternakan, Universitas Sam Ratulangi
}

\begin{tabular}{l} 
K A T A K U N C I \\
\hline Dendeng, Gliserol+NaCl, \\
Penyimpanan
\end{tabular}

\begin{abstract}
A B S T R A K
Penelitian ini dilakukan untuk mengetahui efek gliserol $+\mathrm{NaCl}$ pada dendeng babi yang disimpan pada suhu kamar. Plot split dalam desain waktu digunakan dalam penelitian ini; Faktor A adalah konsentrasi Gliserol + $\mathrm{NaCl}$ (dibagi dalam 3 level kombinasi) sebagai berikut $\mathrm{A}_{1}=$ Gliserol $15 \%+$ $\mathrm{NaCl} 5 \%, \mathrm{~A}_{2}=$ Gliserol $10 \%+\mathrm{NaCl} 10 \%, \mathrm{~A}_{3}=$ Gliserol $5 \%+\mathrm{NaCl} 15 \%$ dan faktor $B$ adalah durasi penyimpanan pada suhu kamar (dibagi dalam 3 lama waktu yang berbeda) sebagai berikut $B_{1}=10$ hari, $B_{2}=20$ hari, $B_{3}=30$ hari; dengan tiga replikasi. Variabel yang diamati adalah kadar air, $\mathrm{pH}$ dan jumlah mikroba. Hasil penelitian menunjukkan bahwa penggunaan Glycerol$\mathrm{NaCl}$ memberikan efek yang sangat berbeda $(P<0,01)$ pada kadar air dan jumlah mikroba pada dendeng babi, tetapi tidak pada $\mathrm{pH}$ dendeng babi. Ditemukan juga bahwa durasi penyimpanan pada suhu kamar memberikan efek yang sangat berbeda $(P<0,01)$ pada semua variabel dendeng babi. Singkatnya, penggunaan Gliserol 5\% + NaCl 15\% dapat memperpanjang umur simpan dendeng babi hingga 30 hari.
\end{abstract}

K E Y W OR D S

Jerky pork, glycerol-NaCl, storage

\begin{abstract}
A B S T R A C T
The study was done in order to know the effect of glycerol+NaCl on jerky pork kept at room temperature. A split plot in time design was used in this study; A Factor was Glycerol+NaCl concentration(divided in 3 combination levels) as follows $\mathrm{A}_{1}=$ Glycerol $15 \%+\mathrm{NaCl} 5 \%, \mathrm{~A}_{2}=$ Glycerol $10 \%+\mathrm{NaCl} 10 \%, \mathrm{~A}_{3}=$ Glycerol $5 \%+\mathrm{NaCl} 15 \%$ and $\mathrm{B}$ factor was duration of storage at room temperature (divided in 3 different length of time) as follows $B_{1}=10$ days, $\mathrm{B}_{2}=20$ days, $\mathrm{B}_{3}=30$ days; with three replications. The variables observed were water content, $\mathrm{pH}$ and the number of microbes. The results showed that the use of Glycerol-NaCl gave significantly a very different effect $(P<0.01)$ on water content and microbial amounts of jerky pork, but not on the $\mathrm{pH}$ of jerky pork. It was found also that the duration of storage at room temperature gave significantly a very different effect $(P<0.01)$ on all variables of jerky pork. In short, the use of Glycerol $5 \%+\mathrm{NaCl} 15 \%$ could extend the shelf life of jerky pork until 30 days.
\end{abstract}

TERSEDIA ONLINE

31 Okotober 2019

\section{Pendahuluan}

Daging babi dan produk olahannya banyak dijual atau dapat dengan mudah ditemukan di berbagai pasar tradisional ataupun berbagai swalayan di kota Manado, karena sebagian besar penduduknya tidak berpantangan mengkonsumsi pangan yang mengandung babi. Sebagai salah satu produk hasil peternakan, daging babi banyak dikonsumsi masyarakat Manado pada umumnya, karena memiliki kandungan nutrient yang tinggi, dimana komposisi daging babi terdiri $71,5 \%$ air, $20,7 \%$ protein, $7,1 \%$ lemak, 3,29\% nitrogen, dengan rasio 3,45\% protein-air,
22,3\% protein-lemak bebas (PFF), 3,54\% nitrogenlemak bebas (NFF) (Egan dkk, 1985).

Sama halnya dengan produk peternakan lainnya, daging babi segar, tidak dapat bertahan atau mudah busuk jika disimpan pada suhu kamar dalam sehari, bahkan kurang dari sehari. Perubahan yang terjadi pada daging babi karena aktifitas mikroba dapat merubah keadaan fisik, kimia dan mikrobiologinya. Oleh sebab itu, upaya pengawetan atau metode/cara pengolahan daging perlu dilakukan. Cara atau metode pengawetan bahan pangan disebut teknologi pengolahan pangan. Teknologi pangan adalah tindakan 
atau proses mengolah/mengawetkan dan mengurangi kerusakan dan kehilangan zat nutrient sehingga aman dikonsumsi. Teknologi pengolahan pangan selain sangat dibutuhkan untuk mencegah terjadinya laju kerusakan agar bahan pangan terjaga baik kualitas dan aman dikonsumsi juga dibutuhkan dalam rangka penganekaragaman (diversifikasi) pangan.

Pengawetan daging bertujuan memperpanjang masa simpan daging untuk jangka waktu yang cukup lama dan kualitas maupun kebersihannya tetap terjaga. Caranya menjaga ketahanan terhadap serangan mikrobia agar daging tidak mudah rusak. Beberapa cara pengawetan yaitu pengeringan, penambahan bahan pengawet (BPP Teknologi, 2000; Ray, 2007). Penambahan pengawet pada daging babi dapat dilakukan dengan menambahkan humektan yang berfungsi menurunkan kadar air dan aktifitas air (Adnan, 1982). Humektan yang sering digunakan adalah dari golongan gula, poliol dan garam. Bahan pengawet dapat digunakan secara tunggal ataupun dapat dikombinasikan, seperti penggunaan gliserol dan $\mathrm{NaCl}$ yang bersifat larut dalam air dan dapat manghasilkan pangan semi basah (Priyantono, 1990). Gliserol rasanya manis kira-kira sepertiga kali kemanisan gula dengan titik didih $1900 \mathrm{C}$ dan tidak bersifat racun (Tranggono dkk, 1990), higroskopis dan mengikat air (Adnan,1982). $\mathrm{NaCl}$ rasanya asin mempunyai tekanan osmotic, bersifat higroskopis (Winarno dkk, 1980). Biasanya pengawetan dapat dilakukan kombinasi antara penambahan bahan pengawet dan pengeringan. Pengeringan berfungsi mengeluarkan air bahan pangan sampai kadar air keseimbangannya (Muchtadi dan Ayustaningwarno,2010), sehingga dapat diawetkan. Proses pengeringan dan penambahan humektan dapat membuat pangan semi basah pada daging yang dikenal dengan dendeng.

Dendeng adalah produk olahan tradisional dari daging yang merupakan hasil kombinasi proses curing dan pengeringan dimana banyak dipakai sebagai menu makanan masyarakat pada umumnya (Muchtadi dan Ayustaningwarno, 2010). Dendeng dapat langsung dengan bumbu segar dan kering atau belum diolah atau disimpan. Penyimpanan dendeng kebanyakan dilakukan pada suhu kamar yaitu suhu 26-270C dengan kelembaban relative $70 \%$. Pendapat lain menyatakan bahwa dendeng merupakan bahan pangan semi basah dengan kadar air 15 sampai 50\% (Purnomo, 1995). Dendeng babi adalah dendeng yang terbuat dari irisan daging babi segar berasal dari babi sehat yang telah diberi bumbu dan dikeringkan (Verma et al, 2013). Sebagai daerah dengan industri peternakan babi yang cukup besar, pengolahan daging babi menjadi dendeng babi belum begitu dikenal dan produk dendeng babi belum banyak beredar di kota Manado. Untuk itu suatu penelitian telah dilakukan untuk mengetahui sejauh mana kualitas dendeng babi yang diberi kombinasi gliserol- $\mathrm{NaCl}$ selama penyimpanan pada suhu kamar

\section{Material dan Metode}

Penelitian ini menggunakan bahan seperti daging babi segar, $\mathrm{NaCl}$, gliserol, $\mathrm{PCA}, \mathrm{NaCl}$ Fisiologis, aquades, alcohol 70\%, dan alat seperti $\mathrm{pH}$ meter, oven, timbangan analitik, blender, botol timbang, desikator, autoclave, incubator, coloni counter dan alat-alat gelas.

Rancangan penelitian adalah petak terbagi dalam waktu (split plot in time) dengan dasar RAL (Steel and Torrie, 1991) dengan ulangan tiga kali. Faktor A kombinasi gliserol $+\mathrm{NaCl}$ terdiri dari: $\mathrm{A} 1=$ Daging babi + (gliserol 15\%-Nacl 5\%), A2 = daging babi + (gliserol 10\%-Nacl 10\%), A3= daging babi + (gliserol 5\%-Nacl 15\%) dan Faktor B lama penyimpanan pada suhu kamar $\left(26-27^{\circ} \mathrm{C}\right)$ terdiri dari: $\mathrm{B} 1=10$ hari, $\mathrm{B} 2=20$ hari, $\mathrm{B} 3=30$ hari. Variabel penelitian adalah kadar air (AOAC, 2005), pH (AOAC, 2005), jumlah mikroba (Fardiaz, 1992).

\section{Hasil dan Pembahasan \\ Kadar Air Dendeng Babi}

Rataan kadar air dendeng babi dapat dilihat pada table 1. Hasil analisis keragaman menunjukkan kombinasi gliserol- $\mathrm{NaCl}$ memberikan pengaruh berbeda sangat nyata $(P<0,01)$ terhadap kadar air dendeng babi, demikian pula lama penyimpanan pada suhu kamar (Tabel 1). Selanjutnya dengan uji BNJ menunjukkan dendeng babi yang menggunakan kombinasi gliserol-NaCl A1 dan A2 kadar airnya sama tapi berbeda nyata $(P<0,05)$ lebih rendah dari A3 (Tabel 1).

Tabel 1. Rataan pengaruh (gliserol + $\mathrm{NaCl}$ ) dan lama penyimpanan pada suhu kamar terhadap

kadar air (\%) dendeng babi.

\begin{tabular}{|c|c|c|c|c|}
\hline Kombinasi & Lama & $\begin{array}{l}\text { Penyimpana } \\
n\end{array}$ & (hari) & Rataan \\
\hline $\begin{array}{c}\text { Gliserol + } \\
\mathrm{NaCl}\end{array}$ & B1 (10) & B2 (20) & $\begin{array}{c}\text { B3 } \\
\text { (30) }\end{array}$ & \\
\hline $\begin{array}{l}\text { A1 } \\
(15 \%+5 \%)\end{array}$ & $43,59 \pm 0,44$ & $\begin{array}{c}47,35 \pm \\
1,69\end{array}$ & $\begin{array}{c}58,29 \\
\pm \\
1,27\end{array}$ & $\begin{array}{c}49,72 \\
\pm 5,71 \\
a\end{array}$ \\
\hline $\begin{array}{l}\text { A2 } \\
(10 \%+10 \%\end{array}$ & $40,96 \pm 1,80$ & $\begin{array}{r}46,86 \\
\pm 1,34\end{array}$ & $\begin{array}{c}56,86 \\
\pm \\
1,83\end{array}$ & $\begin{array}{c}48,21 \\
\pm 5,78 \\
a\end{array}$ \\
\hline $\begin{array}{l}\text { A3 } \\
(5 \%+15 \%)\end{array}$ & $34,47 \pm 2,06$ & $\begin{array}{r}44,72 \\
\pm 0,96\end{array}$ & $\begin{array}{r}44,72 \\
\pm 2,01\end{array}$ & $\begin{array}{c}44,96 \\
\pm \underset{b}{7,18}\end{array}$ \\
\hline Rataan & $39,65 \pm \underset{a}{1,43}$ & $\begin{array}{c}46,31 \\
\pm 1,06^{b}\end{array}$ & $\begin{array}{l}56,93 \\
\pm 2,73\end{array}$ & $\begin{array}{r}47,63 \\
\pm 1,78\end{array}$ \\
\hline
\end{tabular}

Kombinasi Gliserol-NaCl berfungsi secara efektif menurunkan kadar air dendeng babi, namun $\mathrm{Nacl}$ lebih dominan dari gliserol karena sifat higroskopis $\mathrm{Nacl}$ lebih besar dibanding gliserol. Hal ini sejalan dengan Tranggono et al (1990) bahwa $\mathrm{NaCl}$ merupakan elektrolit kuat molekulnya kecil sedangkan gliserol bersifat non elektrolit dan molekulnya besar. Adnan (1982) melaporkan bahwa penggunaan humektan lebih dari satu pada bahan pangan akan terjadi interaksi yang bersifat salting in (humektan yang satu menurunkan koeisien aktifitas humektan yang lain) atau sebaliknya salting out.

Selanjutnya dengan uji BNJ menunjukkan penyimpanan pada suhu kamar B1 berbeda nyata $(\mathrm{P}<0,05)$ lebih rendah kadar air dengan B2 dan 
$B 3$,selanjutnya B2 berbeda nyata $(P<0,05)$ lebih rendah kadar air dengan B3 (Tabel 1). Terjadinya peningkatan kadar air selama penyimpanan pada suhu kamar karena dendeng babi menarik air lingkungan menyesuaikan dengan kelembaban relative ruangan yaitu $70 \%$. Sejalan dengan Purnomo (1990), jika bahan pangan yang dikeringkan akan melakukan kesetimbangan dengan lingkungan dalam hal kandungan air, jika kandungan airnya lebih rendah dari jumlah air kesetimbangannya maka bahan pangan akan menyerap air dari lingkungannya.

\section{pH Dendeng Babi}

Rataan $\mathrm{pH}$ dendeng babi dapat dilihat pada table 2. Analisa keragaman menunjukkan bahwa penggunaan kombinasi gliserol- $\mathrm{NaCl}$ memberi pengaruh yang tidak nyata $(p>0,05)$ terhadap $\mathrm{pH}$ dendeng babi sedangkan lama penyimpanan pada suhu kamar memberikan pengaruh yang berbeda nyata $(\mathrm{P}<0,01)$ pada $\mathrm{pH}$ dendeng babi (Tabel 2$)$.

Tabel 2. Rataan pengaruhi gliserol+ $\mathrm{NaCl}$ dan lama penyimpanan pada suhu kamar terhadap $\mathrm{pH}$ dendeng babi

\begin{tabular}{|c|c|c|c|c|}
\hline Kombinasi & Lama & Penyimpanan & (hari) & Rataan \\
\hline Gliserol+ $\mathrm{NaCl}$ & $\begin{array}{c}\text { B1 } \\
\text { (10) }\end{array}$ & B2 (20) & $\begin{array}{c}\text { B3 } \\
\text { (30) }\end{array}$ & \\
\hline $\begin{array}{l}\text { A1 } \\
(15 \%+5 \%)\end{array}$ & $\begin{array}{l}5,16 \\
\pm \frac{ \pm}{23}\end{array}$ & $5,33 \pm 0,18$ & $\begin{array}{c}5,46 \\
\pm \\
0,18\end{array}$ & $\begin{array}{c}5,52 \pm \\
0,10\end{array}$ \\
\hline $\begin{array}{l}\text { A2 } \\
(10 \%+10 \%)\end{array}$ & $\begin{array}{c}4,96 \\
\pm \\
0,18\end{array}$ & $5,13 \pm 0,18$ & $\begin{array}{r}5,36 \\
\pm 0,16\end{array}$ & $\begin{array}{c}5,15 \pm \\
0,14\end{array}$ \\
\hline $\begin{array}{l}\text { A3 } \\
(5 \%+15 \%)\end{array}$ & $\begin{array}{c}4,63 \\
\pm \\
0,11\end{array}$ & $5,03 \pm 0,11$ & $\begin{array}{c}5,23 \\
\pm 018\end{array}$ & $\begin{array}{c}4,96 \pm \\
0,24\end{array}$ \\
\hline Rataan & $\begin{array}{c}4,92 \\
\pm \\
0,31^{a}\end{array}$ & $5,16 \pm 0,11^{a}$ & $\begin{array}{c}5,35 \\
\pm \\
0,08^{b}\end{array}$ & $\begin{array}{c}5,14 \pm \\
0,16\end{array}$ \\
\hline
\end{tabular}

Selanjutnya uji BNJ menunjukkan B1 dan B2 sama tapi berbeda nyata $(P<0,01)$ B3 lebih tinggi $\mathrm{pH}$ dendeng babi (Tabel 2). Hal ini karena banyaknya jumlah air yang diserap mempengaruhi $\mathrm{pH}$ dendeng babi menjadi meningkat. .Komponen bahan pangan memiliki gugus hidroksil $(-\mathrm{OH})$ yang polar dapat berikatan dengan air melalui ikatan hidogen (Suyitno,1995). Nilai pH dendeng babi yang dihasilkan hampir sama dengan $\mathrm{pH}$ hasil penelitian Verrman et al (2013) yaitu berkisar antara $\mathrm{pH}$ 5,29-6,6. Kenaikan $\mathrm{pH}$ daging juga dapat terjadi akibat perubahan proporsi kimia daging dan hilangnya sebagian cairan daging (Jugde et al., 1989).

\section{Jumlah Mikroba}

Rataan jumlah mikroba dendeng babi dapat dilihat pada tabel 3 . Analisa keragaman menunjukkan bahwa penggunaan kombinasi gliserol-Nacl memberi pengaruh yang berbeda sangat nyata $(P<0,01)$ terhadap jumlah mikroba dendeng babi demikian juga lama penyimpanan pada suhu kamar (Tabel 3).
Table 3. Rataan pengaruh gliserol+NaCl dan lama penyimpanan pada suhu kamar terhadap jumlah mikroba dendeng babi 10 Log (X) (cfu/gram).

\begin{tabular}{|c|c|c|c|c|}
\hline $\begin{array}{l}\text { Kombi } \\
\text { nasi }\end{array}$ & Lama & $\begin{array}{l}\text { Penyimpa } \\
\text { nan }\end{array}$ & (hari) & Rataan \\
\hline $\begin{array}{l}\text { Gliserol+Na } \\
\mathrm{Cl}\end{array}$ & B1 (10) & B2 (20) & B3 (30) & \\
\hline $\begin{array}{l}\text { A1 } \\
(15 \%+5 \%)\end{array}$ & $\begin{array}{l}6,56 \pm 0,1 \\
3\end{array}$ & $\begin{array}{l}6,87 \pm 0,1 \\
3\end{array}$ & $\begin{array}{l}6,93 \pm 0 \\
45\end{array}$ & $\begin{array}{l}6,83 \pm 2 \\
, 00^{a}\end{array}$ \\
\hline $\begin{array}{l}\text { A2 } \\
(10 \%+10 \%)\end{array}$ & $\begin{array}{l}6,36 \pm 0,1 \\
1\end{array}$ & $\begin{array}{l}6,54 \pm 0,0 \\
9\end{array}$ & $\begin{array}{l}6,61 \pm 0 \\
00\end{array}$ & $\begin{array}{l}6,52 \pm 0 \\
, 67^{b}\end{array}$ \\
\hline $\begin{array}{l}\text { A3 } \\
(5 \%+15 \%)\end{array}$ & $\begin{array}{l}6,04 \pm 0,1 \\
8\end{array}$ & $\begin{array}{l}6,42 \pm 0,1 \\
3\end{array}$ & $\begin{array}{l}6,45 \pm 0 \\
04\end{array}$ & $\begin{array}{l}6,32 \pm 0 \\
, 76^{c}\end{array}$ \\
\hline Rataan & $\begin{array}{l}6,36 \pm 0,5 \\
6^{a}\end{array}$ & $\begin{array}{l}6,66 \pm 1,8 \\
9^{b}\end{array}$ & $\begin{array}{l}6,72 \pm 2 \\
24^{\circ}\end{array}$ & $\begin{array}{l}6,60 \pm 1 \\
, 16 \\
\end{array}$ \\
\hline
\end{tabular}

Uji BNJ menunjukkan adanya perbedaan pengaruh antara kombinasi gliserol- $\mathrm{NaCl}$ dendeng babi A1, A2 dan A3 (Tabel 3). Dimana dengan kombinasi semakin banyak $\mathrm{NaCl}$ semakin sedikit jumlah mikroba. Hal ini karena $\mathrm{NaCl}$ mempunyai kemampuan sebagai anti mikroba dari $\mathrm{Cl}^{-}$dan kemampuan osmotik yang menyebabkan plasmolisis (Lawrie,1985), demikian pula gliserol dapat mengendalikan aktifitas air yang dapat menghambat cepatnya pertumbuhan mikroba (Priyantono, 1990). Selain itu menurunnya jumlah air dapat meningkatkan tahap istirahat dan pertumbuhan mikroba karena kegiatan metaboliknya membutuhkan air (Purnomo,1995).

Uji BNJ menunjukkan lama penyimpanan pada suhu kamar B1, B2 dan B3 berbeda sangat nyata $(P<0,01)$ terhadap jumlah mikroba (Tabel 3). Semakin lama penyimpanan maka jumlah mikroba meningkat hal ini karena terjadi peningkatan kadar air dan aktifitas air yang jadi nutrient mikroba dan terjadinya kontaminasi dengan lingkungan serta perubahan suhu dapat mampercepat pertambahanya. Priyantono (1990), bahan pangan mempunyai kandungan air yang lebih rendah dari jumlah air pada kesetimbangannya maka bahan pangan tersebut akan menyerap air dari lingkungannya. Portocarrero et al. (2002) menyatakan bahwa nilai aktivitas air rendah dapat mengendalikan pertumbuhan dan produksi toksin dari bakteri Staphylococcus aureus. Adanya mikrobia ini dapat memicu keracunan makanan dan kondisi ini berkaitan dengan jumlah populasi mikroba dalam makanan. Menurut Wilson et al (1981), daging mulai membusuk bila jumlah mikrobia yang dikandungnya melebihi $5 \times 10^{6}$ $\mathrm{cfu} /$ gram atau $10 \log (\mathrm{x})=6,67 \mathrm{cfu} /$ gram

\section{Kesimpulan}

Penggunaan Gliserol+NaCl dapat memperpanjang masa simpan dendeng babi sampai 30 hari dan yang terbaik adalah Gliserol 5\%+NaCl 15 .

\section{Daftar Pustaka}

Adnan M. 1982.Aktivitas Air dan Kerusakan Bahan Makanan. Penerbit Agritech. Yogyakarta.

AOAC. 2005. Official Methods of Analysis. Association of Official Analytical Chemists. $18^{\text {th }}$ ed. Washington DC. 
Bouton P.E., P.V. Harris and W.R. Shorthose. 1971. Effect of Ultimate $\mathrm{pH}$ Upon the Water-holding Capacity and Tenderness of Mutton. Journal Food. Sci. 36: 435

BPP Teknologi. 2000. Dendeng Sayat. BPP Teknologi Jakarta.

Egan. H., R.S Kirk and R Sawyer. 1985. Pearsons Chemical Analysis of Food. Churchill Livingstone Edinburgh London Melbourne and Newyork

Brewer S.M. and J. Novakofski. 1999. Cooking Rate, $\mathrm{pH}$ and Final Endpoint Temperature Effect on Color and Cooking Loss of a Lean Ground Beef Model System, Meat Sci. 52:44345.

Fardiaz S. 1992, Mikrobiologi Pangan, Penerbit Gramedia Pustaka Utama Jakarta

Lawrie R.A. 2003. Ilmu Daging. Terjemahan A. Parakkasi. Universitas Indonesia Press, Jakarta

Muchtadi T.R., F Ayustaningwarno. 2010, Teknologi Proses Pengolahan Pangan. Alfabeta. Bandung

Portocarrero SM., Newman M., Mikel B. 2002. Staphylococcus aureus survival, Staphylococcal enterotoxin Production and Shelf Stability of Country-cured Hams Manufactured Under Different Processing Procedures. Journal Meat Sci. 62: 267-27.

Purnomo, H. 1995. Aktivitas Air dan Peranannya Dalam Pengawetan Pangan. UI Press. Jakarta

Priyantono. 1990. Teknik Pengawetan Pangan, PAU Universitas Gadjah Mada

Ray F. K. 2007. Meat Curing. Oklahoma Cooperative Extension Service ANSI-3994. Division of Agricultural Sciences and Natural Resources, Oklahoma State University. Oklahoma

Steel R.G.D. and J.H. Torrie.1991. Prinsip dan Prosedur Statistika Suatu Pendekatan Biometrik. Terjemahan Bambang Sumantri. Gramedia Pustaka Utama. Jakarta

Suyitno. 1995. Serat Makan dan Perilaku Aktivitas Air Bubuk Buah, Disertasi. Universitas Gadjah Mada. Yogyakarta

Tranggono., Sutardi., Haryadi., Suparno., A Murdiyati., S Sudarmadji., K Rahayu., Naruki., M Astuti. 1990. Bahan Tambahan Pangan (food additive). Pusat Antar Universitas Pangan dan Gizi. UGM. Yogyakarta

USDA. 2009. USDA Nutrient Data Set for Fresh Pork (From SR), Release 2.0. U.S. Department of Agriculture. Agricultural Research Service. Maryland, USA.

Veerma M., Setiyono, dan Rusman. 2013, Pengaruh Metode Pengeringan dan Konsentrasi Bumbu Serta Lama Perendaman Dalam Larutan Bumbu Terhadap Kualitas Fisik dan Sensori Dendeng Babi, Buletin Peternakan Vol. 37(1): 34-40. Februari 2013. ISSN 0126-4400

Wilson F.G.E., J Dyet., R.B. Hughes, and C.R.V. Jones. 1981. Meat and Meat Products Factor Affecting Quality. Apllied Science Publisher London and New York.

Winarno. 1992. Kimia Pangan dan Gizi. PT Gramedia, Jakarta. 